\title{
The Relationship Between Multiple Role Conflict, Work Expense and Work Stress on The Performance of Women Employees
}

\author{
Ria Zulfiana ${ }^{1}$ \\ Budiyono Pristyadi ${ }^{1}$ \\ Ahmad Qoni Dewantoro ${ }^{1}$ \\ Asep Saepuloh ${ }^{1}$ \\ Alkusani $^{1}$ \\ ${ }^{1}$ Management Study Program, Faculty of Economics and Business \\ Universitas Muhammadiyah Gresik, East Java, Indonesia, \\ asep@umg.ac.id
}

\begin{abstract}
ABSTRAK
Penelitian ini bertujuan untuk mengetahui Pengaruh konflik peran ganda, beban kerja dan stres kerja terhadap kinerja karyawan wanita bagian produksi PT Madsumaya Indo Seafood. Menggunakan metode samplling jenuh merupakan teknik penentuan sampel bila semua anggota populasi digunakan sebagai sampel. Jumlah sampel yang digunakan dalam penelitian ini sebanyak 68 responden. Teknik analisis untuk menguji hipotesis menggunakan Statistical Package for the Social Sciences (SPSS). Teknik analisa data menggunakan analisis regresi liniear berganda. Hasil dari penelitian ini menunjukkan bahwa secara parsial variabel konflik peran ganda tidak berpengaruh negatif terhadap kinerja karyawan wanita bagian produksi PT Madsumaya Indo Seafood, sedangkan beban kerja dan stress kerja berpengaruh negatif terhadap kinerja karyawan wanita bagian produksi PT Madsumya Indo Seafood.
\end{abstract}

Kata Kunci: Konflik Peran Ganda, Beban Kerja, Stres Kerja, Kinerja.

\section{ABSTRACT}

This study aims to determine the effect of multiple role conflicts, workload and work stress on the performance of female employees of the production division of PT Madsumaya Indo Seafood. Using a method is a sampling technique when all members of the population are used as samples. The number of samples used in this study were 68 respondents. The analysis technique for testing hypotheses uses the Statistical Package for the Social Sciences (SPSS). The Technique analysis data used multiple regression linear analysis. The results of this study indicate that partially multiple role conflict variables do not have a negative effect on the performance of female employees in the production division of PT Madsumaya Indo Seafood, while workload and work stress have a negative effect on the performance of female employees in the production division of PT Madsumaya Indo Seafood.

Keywords: Multiple Role Conflict, Workload, Work Stress, Performance.

\section{INTRODUCTION}

A working woman is a woman who acts as a housewife but also works outside the home as a career woman. For working women it is not easy to carry out both roles. In this case, working women can have different performances. This study will reveal the performance of female employees who have multiple role conflicts.
Sodikin $(2017$; 130) Performance is a strategic, comprehensive, and integrated process in conducting periodic reviews and evaluations of the performance of each individual. Women who work and have a family will have a different performance than women who work but are not married. 
The dual role of a woman is mostly carried out by employees of PT Madsumaya Indo Seafood. PT Madsumaya Indo seafood is a company engaged in the processing of fishery products, which produces products with high economic value and is in great demand by the international market. The resulting products are exported to various countries. The phenomenon of multiple roles can be seen from the number of married female employees in the production section of PT Madsumaya Indo Seafood which is dominated by female employees, namely 78 female employees, 68 of whom are women who have multiple roles. It is not an easy thing to carry out both roles, some of them have to live in a boarding house and some of them live in Gresik and Lamongan. For those who live in their boarding house, of course they sacrifice a lot of things for their families for the sake of their careers, of course, less time is given to the family.

In addition, female employees often experience pressure to complete their work as workers and their duties as a family at the same time. Many women take part in activities as workers outside the home which create a lack of harmony in the family. According to Bagger and Andrew (2012: 474) Conflict Dual roles come from work responsibilities that interfere with family responsibilities, or vice versa, family responsibilities interfere with work responsibilities.

Multiple role conflicts can be faced by all women of all professions. PT Madsumaya Indo Seafood employees are one of the professions that are mostly dominated by women. Where employees have a workload, demands for overtime and stay on the job on holidays. So many workers leave their obligation as a wife who has to take care of the house and take care of the children because they come home in the afternoon and at night they sometimes still work overtime. Sundays or holidays also sometimes they use the time for overtime. Therefore, most of the workforce do not have the opportunity to take care of the household and socialize in the community. This can also cause psychological stress they feel.

From the description above, women as employees have the responsibility to complete a number of jobs with high demands for overtime, which is certainly a workload for these employees. If the ability of workers is lower than the demands of the job, there will be more fatigue. According to Koesomowidojo (2017: 19) Employee performance is related to the workload of employees as follows: if worker fatigue increases in completing work that is not in accordance with their physical and mental abilities, it can lead to reduced work capacity and body endurance so that it will have an impact on employee performance decline.

In addition to getting demands from female employees, pressure from the leadership who requires that they comply with the rules is also a concern for them. Superiors do not hesitate to sanction non-compliant employees. Such circumstances make female employees experience stress.

Such individuals often perform tasks better, diligently, or quickly, but too much stress burdens a person with demands that they cannot fulfill, thus showing lower performance (Robbins and Judge, 2014: 377).

As an employee, they are required to always act professionally in their work, especially when facing jobs that have various characteristics. They are required not to confuse family conflicts with temporary work as a wife and a mother, they are also faced with requests from the family so that they continue to carry out their duties as a wife and mother for their children. The workload of the reality suffered by employees from several factors, including the number of uncertain product demand every day, while no additional employees at the request of many, request an exhausting first overtime for employees who must remain logged on holiday. Demands for good quality service from superiors also become a burden and psychological pressures, such as fatigue.

Therefore this research is focused on the effect of multiple role conflict, workload, and 
work stress on the performance of female employees in the production division of PT Madsumaya Indo Seafood.

\section{LITERATURE REVIEW}

\section{Multiple Role Conflict}

Robbins (2016: 305) conflict is a process that begins when one party sees the other party negatively influencing something the first party cares about. Simamora $(2012 ; 182)$ states that conflict is a basic psychological mechanism centered on conflicting goals.

Shein, and Chen (2011: 2) dual role conflict is the mismatch between roles in several ways caused by the pressure of work roles and family roles which become conflicts. So what is meant by conflict in general is the meeting of two different interests at the same time and it can cause negative effects.

Multiple role conflicts in a person that arise due to role pressures from work to family roles. Multiple role conflicts usually occur due to long individual working hours, so that time for families is reduced.

Indicators conflict dual role proposed by Shein, and Chen (2011: 24), namely:

1. Conflict Over Time (Time-Based Conflict) is the time it takes to carry out one of the demands (family or job) can reduce the time to implement the demands of the other ( work or family). Forms of conflict This is positively related to:
a. Number of working hours
b. Overtime
c. Attendance level
d. Shifte irregularity.
e. Work schedule control

2. Pressure Based Conflict (Strain-Based Conflict)

Is the pressure from one role that can affect the performance of other roles. Where are the symptoms of pressure, such as:
a. Tension
b. Anxiety
c. Fatigue
d. Work role characters
e. The presence of new children

f. Availability of social support from family members

3. Behavior-Based Conflict (Behavior-Based Conflict)

Behavior-Based Conflict, in which certain patterns in role-behavior do not match expectations about behavior in other roles. For example:

a. Managerial stereotypes emphasize
aggressiveness
b. Self-confidence
c. Emotional stability
d. Objectivity.

This contrasts with the image and behavior expectations of a wife in the family, who should be caring, sympathetic, nurturant, and emotional.

Thus one can expect that female executives are more likely to experience this form of conflict than male executives, as women have to strive to fulfill the expectations of different roles in the workplace and in the family

\section{Workload}

The smooth running of an organization's activities depends on how many there are numbers. work that must be completed by employees or employees in an organization. Work plays the most important role in organizational components. This is because work is concrete evidence of the existence of an organization. In addition, work is also a tool or media to achieve organizational goals.

Munandar (2010: 383) Workload is a situation where employees are faced with tasks that must be at a certain time. In connection with a person's mental and physical workload, every employee has a different level of workload. A high level of loading allows excessive energy use, which can cause over stress, conversely if the intensity of loading is too low it can cause boredom and boredom or under stress to employees. Therefore it is necessary to balance the intensity level of loading between the two limits and between individuals who are different from one another. 
Employees will be disturbed if the load received is too heavy or too light / little. The number of employees with the same productivity will result in too light workload. Meanwhile, a shortage of workers with a lot of work will cause physical exhaustion psychological.

Workloads can be divided into light, medium, and heavy workloads. Jobs that have a light workload are office workers, doctors, nurses, teachers, and domestic workers who use machines. Jobs that have a moderate workload are light industry, students, construction workers, farmers, shop workers, and domestic workers without using machines. Meanwhile, jobs that have a heavy workload are farmers without machines, porters for lifting / transporting, mining workers, carpenters without machines, ironworkers, dancers and athletes. Meanwhile, according to Koesomowidjojo (2017: 22), there are two types of workloads, namely:

1. Quantitative workload, which shows that there is a large amount of work that must be carried out, such as high working hours, large enough work pressure, or a large amount of responsibility for the work involved. he helped.

2. Qualitative workload, which relates to the ability of workers to carry out the work they are capable of.

Several indicators of workload according to Koesomowidjojo (2017: 33), are as follows:

1. Conditions of Work The conditions of work in question are the extent to which employees are able to understand the job well.

2. Use of Working Time

Minimizing the workload of employees by providing work time in accordance with the SOP.

3. Targets that must be achieved

The work targets for completing the volume of work must be appropriate, so that it takes time to complete work in the organization.

\section{Work Stress}

Daft (2014: 309) Stress is a psychological and emotional response from an individual to external triggers that impose physical or psychological demands on the individual and create uncertainty and a lack of self-control when important results are at stake. These triggers are called stressors that produce a combination of frustration (inability to meet goals, such as inability to meet deadlines due to lack of resources) and anxiety (such as fear of being punished for not meeting deadlines).

Robbins \& Judge (2011: 368) job stress is a condition that is felt by employees, namely due to excessive workload, little time, feelings of difficulty and emotional tension that hinders the performance employee's.

Job stress is basically personal in nature and tends to have a negative effect if there is no balance between the pressure faced by employees and mental endurance in solving the problem. Whether or not work stress is resolved, is greatly influenced by the perceptions of the individual who experiences it. The response that will arise is greatly influenced by this cognitive assessment. An optimal stress level is even needed to keep a person excited and motivated to achieve.

Daft (2014: 10), there are factors that cause work stress, including: job demands and interpersonal demands.

1. The work demands

The demands of work are factors make the stress that comes from work to be done by someone who holds job. a particularSeveral types of decision making tend to be stressful: decisions that are taken under time pressure, or which have serious consequences, and which must be taken with incomplete information.

2. Interpersonal demands Interpersonal Demands are a factor that causes stress related to relationships in organizations. Although in some cases the interpersonal relationships can relieve stress, this relationship can also be a source of stress when group the put pressure on the 
individual or when a conflict occurs between individuals.

Indicators of work stress according to Robbins (2016: 796), namely:

1. Intrinsic factors of work

Factors associated with a person's job such as working conditions, physical layout work, which are job demands.

2. Role in the organization

The role demands in an organization are related to the pressure exerted on someone as a function of a particular role.

3. Relationships at work

Is the pressure created by other employees, which involves relationships with superiors and relationships with coworkers.

4. Career development

Lack of job security regarding organizational leadership such as early retirement or fear of being rehired and status mismatches.

5. Organizational structure and climate

In making decisions less involving employee participation.

\section{Performance}

Performance in an organization is an inseparable element in an organizational institution, be it government institutions or private institutions. Performance as the results of the work function or activities of a person or group in an organization which is influenced by various factors to achieve organizational goals within a certain time.

The function of work or activity that is intended is the implementation of the work results or activities of a person or group that is the responsibility of that person in the organization. Performance is the result or overall success rate of a person during a certain period in carrying out a task compared to various possibilities, such as standards work, targets or targets or criteria that have been determined in advance and have been mutually agreed upon.

Sodikin $(2017 ;$ 130) Performance is a strategic, comprehensive, and integrated process in conducting periodic reviews and evaluations of the performance of each individual.

Widodo, (2015: 133) Performance is influenced by the Quality and Ability of Employees. Namely matters related to education or training, work ethic, work motivation, mental attitudes, and the physical condition of employees.

1. Supporting facilities, namely matters relating to the work environment (occupational safety, occupational health, production facilities, technology) and matters relating to employee welfare (wages / salaries, social security, job security)

2. Supra means, namely matters related to government policy and industrial relations management.

According to Mangkunegara, $(2016 ; 13)$ states that the factors that affect performance are as follows:

1. Ability factors

Job Must be in accordance with their expertise (the right man in the right place, the right man on the right job)

2. Motivation Factors

Motivation is defined as an attitude owned by a leader and employees regarding the work situation in the organization environment. Those who can show a positive or negative value to their work situation, and all of that can show how high or low a motivation that leaders and employees have.

The several factors above, including internal factors, among others: work discipline, job satisfaction and employee motivation. External factors include: leadership style, work environment, compensation and management systems in the company. These factors should be considered by the leadership so that employee performance is optimal.

The characteristics of people who have high performance according to Mangkunegara (2016: 68), are as follows:

1. Having high personal responsibility. 
2. Dare to take and bear the risks faced.

3. Have realistic goals.

4. Have a thorough work plan and strive to realize its goals.

5. Utilizing Feedback Concrete In all work activities he does.

6. Looking for opportunities to realize the plans that have been programmed.

Abdullah, (2014: 145) performance indicators are variables used to express quantitatively the effectiveness and efficiency of processes or operations guided by the goals of the organization.

Chishty (2010: 12), he argues to measure whether employees are performing well at their jobs. Measurement of employee performance can vary based on the nature of the job, type of organization and sector of the organization. In general, performance is measured by:

1. Punctuality of time.

Employees can do certain jobs in a predetermined time.

2. Job Description

A written statement that describes the responsibilities that must be carried out from a particular job.

3. Quantity

A person can complete his work within a predetermined period of time.

4. Quality

Every employee is able to recognize and solve relevant problems and have a positive work attitude in the workplace.

5. Able to cooperate with others.

\section{Hypothesis}

Based on the theoretical basis and framework of thought previously described, the hypothesis in this study is:

1. Multiple roles have no effect on the performance of female production employees

2. workload affect the performance of female production employees

3. Job stress affect the performance of female production employees

\section{METHODE}

This research uses quantitative research, which is one type of research whose specifications are systematic, well-planned and clearly structured from the start to the making of the research design. According to Sugiyono (2017: 8), quantitative research is used to examine specific populations or samples, sampling techniques are generally carried out randomly, data collection uses instruments research, data analysis is quantitative/ statistical with the aim of testing predetermined hypotheses. Quantitative research methods can be defined as a research method based on the philosophy of positivism.

The research location is a place or area where the research will be carried out. In this study, researchers conducted research at PT Madsumaya Indo Seafood in the Gresik Industrial Area Kavling C 8-15. City of Gresik, East Java, Indonesia.

Population is a set of data that has the characteristics same and becomes the object of inference, inference statistics is based on two basic concepts, population as the whole data, both real and imaginary, and the sample, as part of the population used to make inference (approach /describe) the population from which it originates. According to Sugiyono (2017: 80) population is a generalization area consisting of subjects or objects that have qualities and characteristics certain that the research determines to study and draw conclusions.

The population used in this study were all female production employees who were married at PT Madsumaya Indo Seafood. The population of this research is 68 respondents.

Sugiyono (2017: 81) samples are some parts taken from the population from the total number and characteristics of the population. must truly be representative (representing). The sample size is the number of samples to be taken from a population. According to Arikunto (2017: 73), if the population is less than 100 people, the total sample is taken as a whole, but if the population is greater than 100 people, it 
can be taken $10-15 \%$ or $20-25 \%$ of the total population.

Based on the above theory, the researcher used a saturated sampling technique, namely the sampling technique if all members of the population were used as samples. Saturated sample is also called the census in which all members of the population are sampled. From the total population of 68 female production employees at PT Madsumaya Indo Seafood, the researchers took the overall sample of the population as many as 68 people.

In this study, the type of data used by researchers is primary data, namely a questionnaire as a research instrument, used to produce quantitative data, the Likert scale as the measurement scale. The analysis technique used in this research is validity test, reliability test, classical assumption test, multiple linear regression equation, coefficient of determination and $\mathrm{t}$ test.

\section{RESULTS AND DISCUSSION}

The results of the test at the initial stage were tested with validity tests, reliability tests, classical assumption tests, in this test the results showed that all measuring instruments had met the required criteria, so that the next stage of testing, namely regression analysis, could be carried out. The results of the regression analysis that have been obtained are described as follows.

The results of the research on the multiple role conflict variable (X1) obtained the value of $\mathrm{t}$ count $(-0.572)<\mathrm{t}$ table (1.998), with a significant level of $5 \%$, so Ho is accepted and $\mathrm{H} 1$ is rejected, meaning that partially the Multiple Role Conflict variable (X1) has no effect. (negative) on the performance $(\mathrm{Y})$ of female employees of the production division of PT. Madsumaya Indo Seafood. The results of the research workload variable (X2) obtained $t$ value (5.998)> $t$ table (1.998), with a significant level of $5 \%$, so $\mathrm{Ho}$ is rejected and $\mathrm{H} 1$ is accepted, meaning that partially the Workload variable (X2) has a significant (negative) effect. on the performance $(\mathrm{Y})$ of female production employees of PT. Madsumaya Indo Seafood. The results of the research workload variable (X2) obtained t value (5.998)> t table (1.998), with a significant level of 5\%, so Ho is rejected and $\mathrm{H} 1$ is accepted, meaning that partially the Workload variable (X2) has a significant (negative) effect. on the performance (Y) of female production employees of PT. Madsumaya Indo Seafood.

Based on testing the hypothesis about the effect of multiple role conflict, workload and work stress on the performance of female employees in the production division of PT Madsumaya Indo Seafood, researchers can interpret the results as follows:

1. Multiple role conflict variables have no effect (negative) on the performance of female employees in the production division of PT Madsumaya Indo Seafood. . The negative direction shows that multiple role conflicts cannot reduce performance. The value of $\mathrm{t}$ count $(-0.572)<\mathrm{t}$ table (1.998), with a significant level of $5 \%$, it is evident that multiple role conflicts are not able to be a determining factor in the decline in the performance of female employees in the production section of PT Madsumaya Indo Seafood. In accordance with Bagger and Andrew's opinion (2012: 474) Conflict Multiple roles come from work responsibilities that interfere with family responsibilities. Supported by research conducted by Hudalifah (2014) which shows multiple role conflicts do not have a negative effect on performance. This is because female employees think that if they decide to work by carrying out their responsibilities as a family role as well as a role as workers, the employees have already accepted the risks of that role. Female employees can get around by solving household problems by giving household matters to their spouses (husbands) or entrusting them to child caregivers.

2. Workload variables have an effect (negative) on the performance of female employees in the production division of PT Madsumaya 
Indo Seafood. The positive direction shows that the workload can reduce performance. The value of $t$ count (5.998)> t table (1.998), with a significant level of $5 \%$, it is evident that the workload variable affects the performance of female employees in the production division of PT Madsumaya Indo Seafood. In accordance with his opinion Koesomowidojo (2017: 19), if the increased fatigue of workers in completing their work that is not in accordance with their physical and mental abilities, it can cause a reduction in work capacity and body endurance so that it will have an impact on decreasing employee performance. Supported by research conducted by Ramli (2016), which shows workload has a significant effect on employee performance. This is because employees female feel that if the work is too burdensome to carried beout continuously without any additional workers, it will cause fatigue which affects the decline in performance. female employees feel that the time used for work is too excessive, resulting in less free time they use for rest and vacations. In addition, female employees feel that there are too many targets to be achieved because they often feel tired at work.

3. Work stress variable has an effect (negatively) on the performance of female employees in the production division of PT Madsumaya Indo Seafood. The positive direction shows that job stress can reduce performance. The value of $t$ count (8.797)> $\mathrm{t}$ table (1.998), with a significant level of $5 \%$, it is evident that the work stress variable affects the performance of female employees in the production division of PT Madsumaya Indo Seafood. In accordance with the opinion of Robbins and Judge, (2014: 377) low to medium stress levels encourage the body and increase its ability to react. Such individuals often perform tasks better, more diligently, or quickly, but too much stress burdens a person with demands that cannot be fulfilled, resulting in lower performance. Backed by research conducted Chandra and Ardiansyah (2017), which shows the work stress has a significant influence on employee performance. This is because female employees feel that too much work pressure without appreciation will cause emotional tension which has an impact on decreased performance. Female employees fear job security, such as layoffs without severance pay or layoffs temporarily.

\section{CONCLUSION}

Multiple role conflicts do not have a partial negative effect on the performance of female employees in the production division of PT Madsumaya Indo Seafood, Workload has a partially significant negative effect on the performance of female employees in the production division of PT Madsumaya Indo Seafood and then Job stress has a partially significant negative effect on the performance of female employees in the production division of PT Madsumaya Indo Seafood.

Based on the results of the analysis, discussion and research conclusions, the recommendations from researchers can be given as follows: For companies, It is recommended to pay attention to and provide support to employees if they experience multiple role conflicts so as not to interfere with their performance, you should adjust the workload to the ability of employees and pay attention to conditions and standards work in the company, it is better to maintain cohesiveness between superiors and subordinates as well as to reward employee appreciation for employees in completing work so that they can work together to achieve satisfactory work results and improve employee performance. For further research, this research can be used as a reference and furthermore by increasing the number of variables or looking for phenomena in the field that can affect performance. Namely matters related to education or training, work ethic, work motivation, mental attitudes, organizational 
culture, leadership styles in the company, and others. By using different analytical techniques and methods to find out the difference between the previous and current analysis..

\section{REFERENCES}

Abdullah, M. Ma'ruf, (2014), Manjemen dan Evaluasi Kinerja Karyawan, Aswaja Pressindo, Yogyakarta.

Aisyah, Siti, (2019). Analisis Peran Ganda Pekerja Wanita di BPJS Ketenagakerjaan Gresik.

Arikunto, Suharsimi, (2013), Prosedur Penelitian Suatu Pendekatan Praktik. Rineka Cipta, Jakarta

Bagger, Jessica., Andrew Li. (2012), Being important matters: The impact of work and family centrlities on the family-to-work conflict-satisfaction relationship. Joernal of human relations, 65:473

Chandra, Riny., \& Dody Adriansyah. (2017). Pengaruh Beban Kerja dan Stres Kerja Terhadap Kinerja Karyawan pada PT Mea Auto Central Finance Cabang di Langsa.

Chrishtiy, Saeed ul hasan, Rafiq, M. Rahman, F. Junani, Nabi Bux, Ajmal, M, (2010). Impact of participative Management on employee Job Satisfaction and Performance in Pakistan. Journal Academic. Vol 10.hal 12-13

Daft, Richard L, (2014), Era Baru Manajemen, Edisi 9 buku 2, Salemba Empat, Jakarta.

Ghozali, Imam, (2011), Aplikasi Analisis Multivariate dengan Program IBM SPSS. Edisi kelima. Semarang: Badan Penerbitan Universitas Diponegoro. Hal.19- 229

Ghozali, Imam, (2013), Aplikasi Analisis Multivariate dengan Program IBM SPSS 21 Update PLS Regresi, Badan Penerbit Universitas Diponegoro, Semarang.

Ghozali, Imam, (2016). Aplikasi Analisis Multivariete Dengan Program IBM SPSS 23 (Edisi 8), Cetakan ke VIII, Badan Penerbit Universitas Diponegoro, Semarang.
Hasibuan, Melayu S.P, (2011), Manajemen Sumber Daya Manusia. Bumi Aksara, Jakarta.

Hudalifah, Nurul, (2014). Pengaruh Konflik Peran Ganda dan Stres Kerja Terhadap Kinerja Perawat Wanita Rumah Sakit Muhammadiyah Gresik.

Koesomowidjojo, Suci r. Mar'ih, (2017). Panduan Praktis Menyusun Analisis Beban Kerja, Jakarta.

Mangkunegara, Anwar Prabu, (2016), Manajemen Sumber Daya Manusia Perusahaan, Cetakan ketiga belas, PT. Remaja Rosdakarya, Bandung.

Munandar, S. Ashar, (2010), Psikologi Industri dan Organisasi, Universitas Indonesia, Jakarta

Nauli, Gabriela Grace, (2018). Pengaruh Konflik Peran Ganda (Work-Family Conflic) dan stress KerjaTerhadap Kinerja Karyawan pada PT Indah Jaya Textile Industry di Kabupaten Bandung.

Ramli, Hera Wati, (2016). Pngaruh Konflik Peran Ganda, Beban Kerja dan Kelelahan Kerja (Burnout) dengan Kinerja Perawat Wania di RSUD 1 Lagaligo Kabupaten Luwu Timur.

Robbins, Stephen P dan Timothy A Judge, (2011), Perilaku Organisasi Edisi Keduabelas, Salemba empat, Jakarta.

Robbins, Stephen P dan Timothy A Judge.,(2014), Perilaku Organisasi. Salemba Empat, Jakarta.

Robbins, Stephen P. and Mary Coulter, (2016), Manajemen, Jilid 1 Edisi 13, Alih Bahasa: Bob Sabran Dan Devri Bardani P, Erlangga, Jakarta.

Sedarmayanti, (2013), Manajemen Sumber Daya Manusia. Cetakan kelim, PT. Remaja Sodakarya, Bandung.

Sedarmayanti, (2015), Manajemen Sumber Daya Manusia. reformasi \& birokrasi Pegawai Negeri Sipil. Refika Aditama, Bandung.

Shein, J., Chen, C. P., (2011), Work-family enrichment a research of positive transfer, Sense Publishers: Canada. 
Sinambela, Lijan Poltak, (2017), Manajemen Sumber Daya Manusia. PT Bumi Aksara, Jakarta.

Sodikin, Dikdick, Djaka P, Suhenda A, (2017), Manajemen Sumber Daya Manusia, Salemba Empat, Jakarta

Sugiyono, (2017), Metode Penelitian Kuantitatif, Kualitatif dan R\&D, Alfabeta, Bandung.

Sujarweni, V, Wiratna, (2015), Akuntansi Manajemen, Pustaka Baru Press, Yogyakarta.

Sutrisno, Edy, (2016), Manajemen Sumber Daya Manusia. Prenadamedia Group, Jakarta.

Umam, Khaerul, (2010), Prilaku Organisasi Bisnis. Pustaka Setia: Bandunng. 